\section{Timed Release of Flurprimidol from a Granular Formulation in Mulches and Sand}

\author{
Timothy L. Grey ${ }^{2}$ \\ University of Georgia, Crop and Soil Sciences, 115 Coastal Way, Tifton, GA \\ 31794
}

Mark Czarnota
University of Georgia, Department of Horticulture, 1109 Experiment Street,
Griffin, GA 30223

Thomas Potter

USDA-ARS Southeast Watershed Research Laboratory, P.O. Box 748, Tifton, GA 31793

\section{B. Todd Bunnell ${ }^{1}$ \\ Turf and Landscape Research, SePRO Corporation, Carmel, IN 46032}

Additional index words. growth regulator, dissipation time, $\mathrm{DT}_{50}$, exponential decay equation pine bark media, hardwood bark media

\begin{abstract}
Flurprimidol is a plant growth regulator that can be applied as a granular formulation. Understanding flurprimidol release from a granular formulation and movement in various mediums will impact how it is used. Dissipation of flurprimidol from a granular formulation and movement through organic media and sand were evaluated in a greenhouse and laboratory experiment. Experimental variables included media type, depth, and irrigation event. Dissipation isotherms were determined by applying nonlinear regression. Mobility was evaluated using columns filled with media, which was surface-spiked with the granular formulation and then irrigated once daily for 22 consecutive days. Leachate was collected and analyzed by high-performance liquid chromatography-mass spectroscopy. Half-life $\left(\mathrm{DT}_{50}\right)$, defined as time to $50 \%$ reduction, varied among sand, media, and media depth. Flurprimidol dissipation was rapid through sand with $\mathrm{DT}_{50}$ of 6 days. $\mathrm{DT}_{50}$ increased with increasing media depth from 5 to $10 \mathrm{~cm}$ for pine bark plus sand, 18 and 35 days, and hardwood bark plus sand, 77 and 173 days, respectively. Maximum flurprimidol leaching was a cumulative $71 \%$ of applied amounts over 22 irrigation events through the sand. Hardwood and pine bark media allowed less than $25 \%$ of flurprimidol to escape through the column. Data for all media indicated that flurprimidol was mobile through the substrates but exhibited hysteresis with pine bark and hard wood bark media. An initial pulse of flurprimidol will release slowly from this formulation over time. These results indicate that flurprimidol will dissipate from a granular formulation over time and that it will have movement through sand soil and pine bark and hardwood bark media to reach the roots of growing plants.
\end{abstract}

Flurprimidol [alpha-(1-methylethyl)-alpha(4-(trifluoromethoxyphenyl)-5-pyrimidinemethanol] is a commercially available Type II plant growth regulator (PGR) (Rademacher, 2000) registered for use on golf course turf, coniferous and deciduous trees, established landscape ornamental plants and shrubs, and ornamental plants grown in containers (Anonymous, 1989). Totten et al. (2006) reviewed the physiological PGR effects of flurprimidol and stated that flurprimidol is predominantly root absorbed. Sev-

Received for publication 4 Nov. 2008. Accepted for publication 4 Jan. 2009.

We thank SePro Corp., Carmel, IN, for their partial financial support of this research.

${ }^{1}$ Manager.

${ }^{2}$ To whom reprint requests should be addressed; e-mail tgrey@uga.edu.
Granular formulations of herbicides and PGRs are used to promote controlled release and reduce the number of applications (Gilliam et al., 1992; Keel et al., 1998). Granular herbicide formulations include oryzalin, flumioxazin, isoxaben, metolachlor, pendimethalin, imazapyr, tebuthiuron, ethalflurlin, diuron, and various combinations of these chemistries [Weed Science Society of America (WSSA), 2007]. Herbicidal activity of each is dependent on chemical properties and formulation. For example, among the dinitroaniline herbicides, pendimethalin has greater water solubility $\left(0.275 \mathrm{mg} \cdot \mathrm{L}^{-1}\right)$ and lower volatility (WSSA, 2007), which makes it more conducive for granular application in ornamental container production systems.

For flurprimidol granular products, the exact formulation properties are confidential, being best described as an inert granule coated with flurprimidol at $0.33 \%$ by weight. As previously described, flurprimidol has moderate water solubility, but also activity at low concentrations (Lembi and Chand, 1992; Nelson, 1996, 1997), making it ideal for use as a PGR applied as a granular formulation. However, there is no information available about flurprimidol release characteristics and movement with respect to soil and organic media layers such as mulch and other soil barriers and covers, which are often used in landscape ornamental beds. The objective of this research was to determine flurprimidol dissipation rates from a flurprimidol-coated granule and to compare directly the movement of flurprimidol in sand, pine bark, and hardwood bark.

\section{Materials and Methods}

Greenhouse studies were conducted in 2007 to compare flurprimidol dissipation from a granular formulation applied to sand, pine bark, and hardwood bark using benchtop lysimeters. Lysimeters were constructed from $30 \mathrm{~cm}$ wide $20 \mathrm{~cm}$ deep circular polyvinyl chloride (PVC) pipe (Industrial Wholesalers Incorporated, Griffin, GA) with a PVC end cap (Industrial Wholesalers Incorporated). All sections of pipe and cap were first cleaned using methyl-ethyl-ketone and an acetone-based cleaner (Oaty Supplies, Cleveland, $\mathrm{OH}$ ) and then allowed to dry. A section of pipe and cap were then coated with an all purpose solvent weld (Industrial Wholesalers Incorporated) and the cap fitted to one end of the pipe and sealed. Each tube was held until the weld had set $(\approx 2 \mathrm{~min})$ and allowed to dry for $2 \mathrm{~d}$. A $2.5-\mathrm{cm}$ hole was then drilled in the bottom center of the PVC lysimeter unit, and a $34 \mathrm{~mm}$ wide $\times 55$-mm long polypropylene funnel (Fisher Scientific, Pittsburgh, PA) was then glued into the hole with clear silicone (GE Sealants \& Adhesives, Huntville, NC). Before gluing to the base of the lysimeter, the funnel was loosely filled with glass wool (Oaty Supplies). An 18/14 mesh fiberglass screen (www.fiberglassscreen.com/index. $\mathrm{htm}$ ) was cut to a $30-\mathrm{cm}$ diameter and placed in the bottom of each lysimeter. The lysimeter bodies, funnel side down, were then 
placed between two treated $5 \mathrm{~cm}$ thick $\times 10$ $\mathrm{cm}$ wide $\times 2.4-\mathrm{m}$ long boards that were screwed onto the bottom of 22.7-L buckets. This whole system was placed onto a greenhouse bench. Lysimeters were held in place by gravity. Greenhouse temperature ranged from $20( \pm 5)$ to $30( \pm 5)^{\circ} \mathrm{C}$ for the duration of the experiment with natural lighting.

Two media components, pine bark (Evergreen Company, Muscle Shoals, AL) and hardwood bark (Evergreen Company) and one sand (premium play sand; Quikrete, Atlanta, GA) were used in the flurprimidol granule leaching and movement studies. The pine and hardwood bark represented an organic mulch layer typical of those used by end users to cover bare soil in landscape beds. The physical and chemical analysis included bulk density, hydraulic conductivity, and volume of voids (Simmons and Derr, 2007). Chemical analysis and percent sand, silt, and clay for the soil were conducted by the University of Georgia Soil, Plant, and Water Laboratory in Athens. Analysis included $\mathrm{pH}$, percent organic matter, and percent organic carbon.

All columns were first uniformly packed with a $1.3-\mathrm{cm}$ layer of the sand. Columns containing media, which also contained the $1.3-\mathrm{cm}$ layer of sand as a base, were uniformly packed with equal amounts of pine bark or hardwood bark to depths of either 5 or $10 \mathrm{~cm}$. Each treatment (five in total) contained three replications. Treatments were arranged as a randomized complete block design on the greenhouse bench. Before treatment with flurprimidol, all lysimeters were watered once daily for 14 consecutive days with $1.3 \mathrm{~cm}$ of irrigation water using an overhead sprinkler system. The irrigation system was constructed on the table and consisted of four risers containing overhead Netafim sprinkler heads (Netafim sprinkler head \#VS-GN; Hummert International, Earth City, MO). Flushing was conducted to remove any water-soluble contaminates (from construction) and to ensure the lysimeter system was flowing properly.

Surfaces of each lysimeter were treated with $11.9 \mathrm{mg}$ flurprimidol using the $0.33 \%$ granular formulation (Cutless; SePRO Corporation, Carmel, IN) by uniformly spreading flurprimidol on the surface of the lysimeter. This volume corresponded to a flurprimidol field use rate of $1.7 \mathrm{~kg} \cdot \mathrm{ha}^{-1}$ ai (Anonymous, 1989). Immediately after treatment, $2.5 \mathrm{~cm}$ of water was applied to all lysimeters. Water passing through the lysimeter was collected for $2 \mathrm{hr}$ after irrigation. Two additional empty lysimeters were used in the study. One was used to collect a volume of water applied for each irrigation event. The other lysimeter was treated with the same rate of flurprimidol and served as a control to monitor for potential contamination of granular product moving through the glass wool. After each irrigation event, $2 \mathrm{~mL}$ of leachate from each lysimeter was transferred to a sealable $2-\mathrm{mL}$ tube (Fisher Scientific) and then stored in a freezer at $-10{ }^{\circ} \mathrm{C}$. For all studies, care was taken to prevent contamination between sam- ples and to collect a representative sample from each lysimeter. Leachate was recorded for each lysimeter for each irrigation event. This process was repeated daily for 22 consecutive days.

Leachate samples were analyzed for flurprimidol by direct aqueous injection-

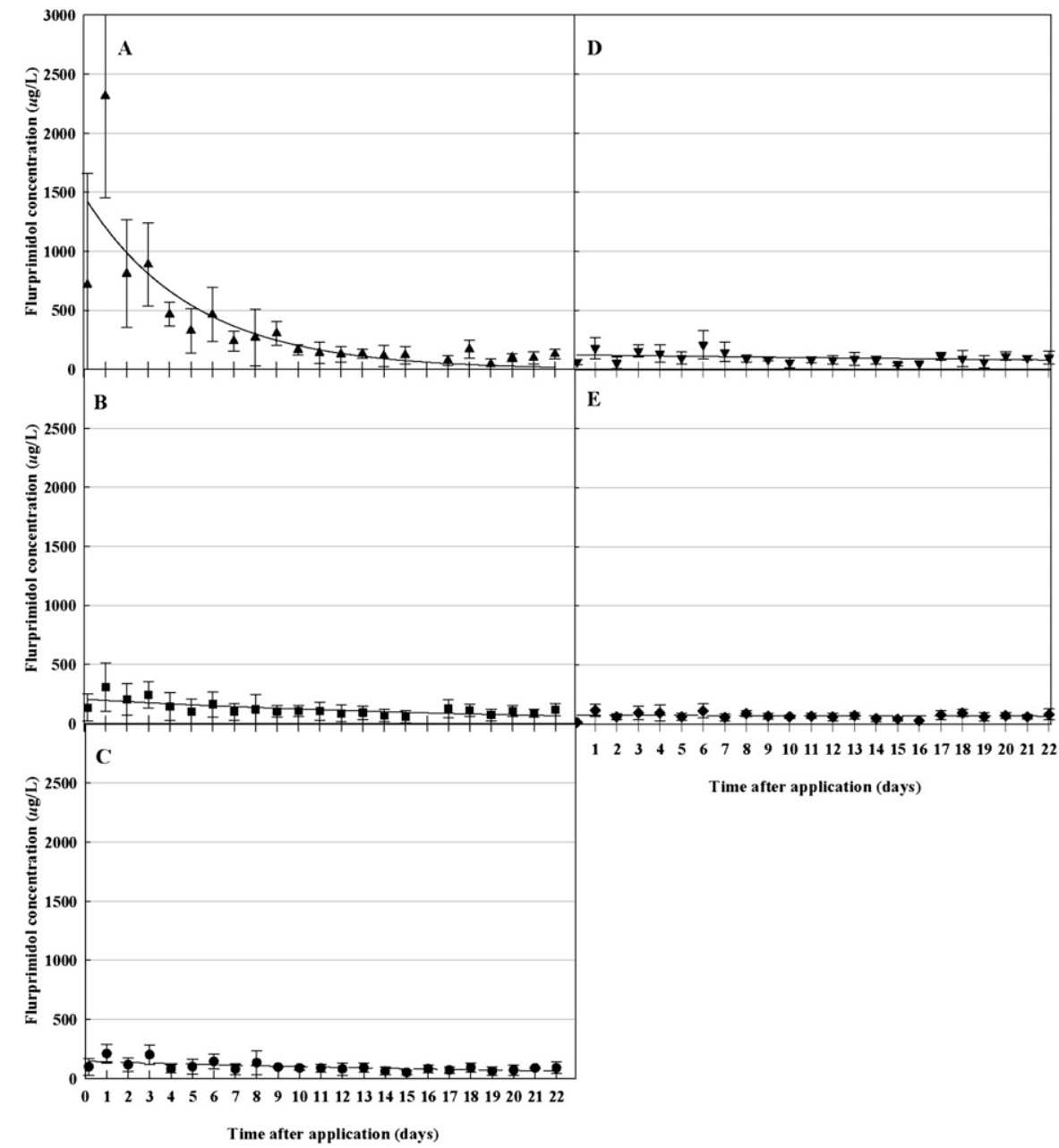

Fig. 1. Flurprimidol release from a granular formulation for sand and media using the exponential decay equation. General linear models procedures were used with mean separation using $95 \%$ asymptotic confidence intervals. Data points are the means of three replications with bars indicating the SE of the mean. NS = nonsignificant.

\begin{tabular}{|c|c|c|c|c|}
\hline$A$ & Sand & $1.3 \mathrm{~cm}$ deep & $\gamma=7034 e^{-0.125 x}$ & $P<0.001$ \\
\hline & Pine bark plus sand & $5+1.3 \mathrm{~cm}$ deep & $\gamma=195 e^{-0.039 x}$ & $P<0.001$ \\
\hline & Pine bark plus sand & $10+1.3 \mathrm{~cm}$ deep & $\gamma=92 e^{-0.020 x}$ & $P=\mathrm{NS}$ \\
\hline & Hard wood bark plus sand & $5+1.3 \mathrm{~cm}$ deep & $\gamma=119 e^{-0.009 x}$ & $P=\mathrm{NS}$ \\
\hline & Hard wood bark plus sand & $10+1.3 \mathrm{~cm}$ deep & $\gamma=72 e^{-0.004 x}$ & $P=\mathrm{NS}$ \\
\hline
\end{tabular}

Table 1. First-order rate constants $(\mathrm{k})$ and half-lives $\left(\mathrm{DT}_{50}\right)$ of flurprimidol release from a granular formulation in media and sand soil.

\begin{tabular}{lccc}
\hline Medium & Depth $(\mathrm{cm})$ & $\begin{array}{c}\text { First-order rate } \\
\text { constant }^{\mathrm{z}} \text { per event }\end{array}$ & DT $_{50}(\mathrm{~d})$ \\
\hline Sand soil & 1.3 & $0.125 \mathrm{a}^{\mathrm{y}}$ & 6 \\
Pine bark media plus sand soil & $5+1.3$ & $0.039 \mathrm{~b}$ & 18 \\
Pine bark media plus sand soil & $10+1.3$ & $0.020 \mathrm{~b}$ & 35 \\
Hardwood bark media plus sand soil & $5+1.3$ & $0.009 \mathrm{~b}$ & 77 \\
Hardwood bark media plus sand soil & $10+1.3$ & $0.004 \mathrm{~b}$ & 173 \\
\hline
\end{tabular}

${ }^{\mathrm{z}}$ First-order dissipation rate constants were calculated by nonlinear regression of flurprimidol quantity with respect to time ( 0 to $22 \mathrm{~d}$ ).

${ }^{y}$ Values for each media for first-order rate constants within a column followed by the same letter are not significantly different. General linear models procedures were used with mean separation using $95 \%$ asymptotic confidence intervals. 
$20 \%$ HPLC-grade water. Flow rate was $1 \mathrm{~mL} /$ min. The mass filter was scanned from 200 to 400 Daltons during data 5-min acquisition. The base peak in the mass spectra, which corresponded to the compound's protonated molecular ion, $\mathrm{m} / \mathrm{z}=313$, was used for quantitation. Aqueous standards were prepared using technical-grade flurprimidol (flurprimidol, technical grade; SePRO Corporation). Instrument response was linear $\left(R^{2}>0.999\right)$ over the concentration range of 0.05 to 10 $\mu \mathrm{g} \cdot \mathrm{mL}^{-1}$. The instrument was tuned by flow injection of a flurprimidol dissolved in methanol before each evaluation. Instrument parameters were optimized to give maximum response for $\mathrm{m} / \mathrm{z}=313$.

Data were subjected to analysis of variance with the use of a mixed model in which media and soil components and depth were fixed effects and replications were random effects. Data points are the means of three replications with bars indicating the SE of the mean. The intent was to determine if the response could be described by using the exponential decay equation:

$$
y=B_{0} \mathrm{e}_{1}^{-B(x)}
$$

where $y$ is soil/media flurprimidol concentration, the coefficient $B_{0}$ is the initial concentration $\left(\mu \mathrm{g} \cdot \mathrm{L}^{-1}\right), B_{I}$ is dissipation rate, and $x$ is time in days after transplanting (DAT). After data were regressed against time in days, the output from the analysis included the firstorder dissipation rate constant $(k)$ (Ohmes et al., 2000). The rates of release (slope of the regression) for media and soil for common parameters were compared using general linear models procedures with mean separation using $95 \%$ asymptotic confidence intervals. The 95\% asymptotic confidence intervals were used to determine significance for the exponential decay equation.

Flurprimidol percent accumulation over time was evaluated using the exponential rise to maximum equation:

$$
y=\propto\left(1-\mathrm{e}_{1}^{-B(x)}\right)
$$

where the coefficient $\propto$ is predicted, asymptotic maximum, $B_{I}$ represents the leaching of flurprimidol with subsequent irrigation events, and $x$ is time in DAT.

Dissipation time (50\%) was determined using the equation:

$$
\mathrm{DT}_{50}=(\ln 2) / \mathrm{k}
$$

(Dermiyati and Yamamoto, 1997; Mueller et al., 1999). All data were then graphed (SigmaPlot for Windows Version 10.0; SPSS Inc., Chicago, IL).

\section{Results and Discussion}

Analysis of organic media and soil. Pine bark, hardwood bark, and the sand organic matter contents (from ignition weight loss) were $80 \%, 68 \%$, and $0 \%$, and $\mathrm{pHs} 6.0,6.4$, and 6.5 , respectively. Bulk densities were $0.16,0.17,1.5 \mathrm{~g} \cdot \mathrm{cm}^{-3}$ for pine bark, hardwood bark, and sand, respectively. The results of analysis were similar to other reports for pine bark (Brown and Pokorny, 1975; Daniels and Wright, 1988; Grey et al., 1996; Simmons and Derr, 2007) and hardwood bark (Brake et al., 1992). The sand was $90 \%$ sand, $0 \%$ silt, and $10 \%$ clay. Pine bark, hardwood bark, and sand macropore space were $54 \%, 65 \%$, and $6 \%$, whereas waterholding capacity was $79 \%, 134 \%$, and $30 \%$, respectively. Simmons and Derr (2007) reported similar pore space volumes for pine bark and Grey et al. (1996) reported similar gravimetric waterholding capacity for pine bark. Hardwood bark was very absorptive to water.

Analysis of data indicated that flurprimidol dissipation data could not be combined across media depth for presentation. Therefore, data by media depth are presented separately with first-order rate constants presented by treatment.
Dissipation from granules and mobility. Flurprimidol dissipation from the formulated granules alone was similar to the sand treatment (data not presented). The exponential decay (Eq. [1]) effectively described flurprimidol dissipation $(P<0.0001)$ from the granules for the sand (Fig. 1A). First-order dissipation rate constant $(k)$ for flurprimidol was 0.125 in sand and was significantly greater than pine bark and hardwood bark mulches (Table 1). Flurprimidol half-life $\left(\mathrm{DT}_{50}\right)$ as defined as time to $50 \%$ reduction was $6 \mathrm{~d}$ for the sand. For pine bark plus sand, flurprimidol quantification by exponential decay [1] dissipation constant $(k)$ was not different for the 5- (0.039) and 10-cm (0.020) depths. However, the $\mathrm{DT}_{50}$ increased from 18 to $35 \mathrm{~d}$ with the increase in depth, respectively. This same effect occurred with hardwood bark plus sand where there were no differences for flurprimidol dissipation

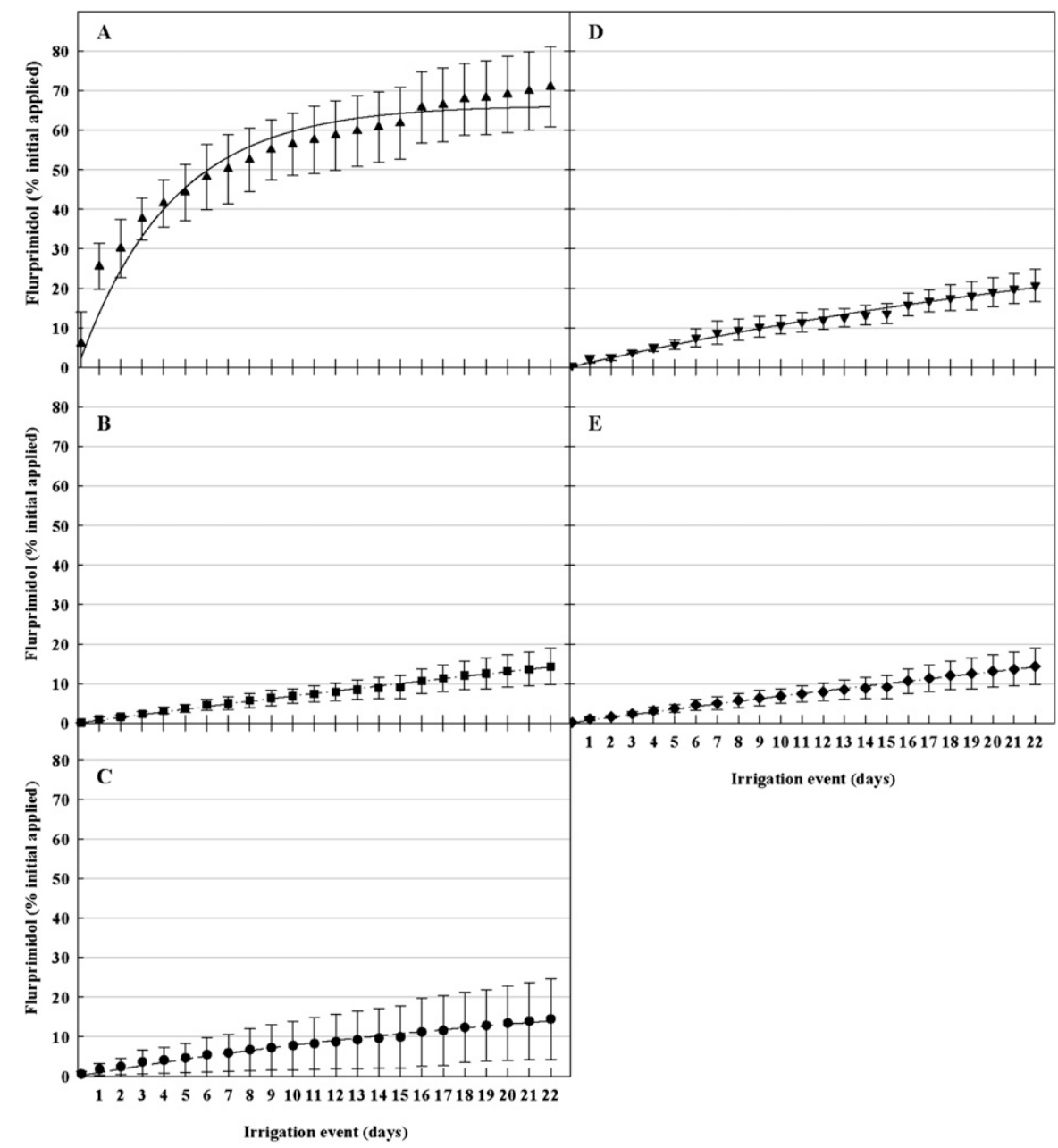

Fig. 2. Flurprimidol accumulation over time from a granular formulation for sand and media using the exponential rise to maximum equation. General linear models procedures were used with mean

\begin{tabular}{|c|c|c|c|c|}
\hline$\overline{\mathrm{A}}$ & Sand & $1.3 \mathrm{~cm}$ deep & $\gamma=66.3\left(1-e^{-0.231 x}\right)$ & $P<0.001$ \\
\hline B & Pine bark plus sand & $5+1.3 \mathrm{~cm}$ deep & $\gamma=71.4\left(1-e^{-0.010 x}\right)$ & $P=\mathrm{NS}$ \\
\hline $\mathrm{C}$ & Pine bark plus sand & $10+1.3 \mathrm{~cm}$ deep & $\gamma=24.1\left(1-e^{-0.040 x}\right)$ & $P=\mathrm{NS}$ \\
\hline $\mathrm{D}$ & Hard wood bark plus sand & $5+1.3 \mathrm{~cm}$ deep & $\gamma=43.2\left(1-e^{-0.029 x}\right)$ & $P<0.001$ \\
\hline E & Hard wood bark plus sand & $10+1.3 \mathrm{~cm}$ deep & $\gamma=31.8\left(1-e^{-0.064 x}\right)$ & $P=\mathrm{NS}$ \\
\hline
\end{tabular}
separation using $95 \%$ asymptotic confidence intervals. Data points are the means of three replications with bars indicating the SE of the mean. NS = nonsignificant. 
constants $(k)$ between the 5- $(0.009)$ and 10$\mathrm{cm}(0.004)$ media depths. However, the $\mathrm{DT}_{50}$ were much greater at 77 and $173 \mathrm{~d}$, respectively. Initial differences in flurprimidol recovery were noted by the $y$-intercepts with the sand at $7034 \mu \mathrm{g} \cdot \mathrm{L}^{-1}$, which was at least $36 \times$ greater than any of the other media-sand combinations (Fig. 1). These data indicate that flurprimidol movement was inhibited by pine and hardwood barks. In pine bark plus sand and hardwood bark plus sand, flurprimidol concentrations were continually replenished with each irrigation event. Because the barks were used in combination with the sand, these data indicate that pine and hardwood media were adsorptive to flurprimidol. This would decrease flurprimidol dissipation and extend activity in systems that use bark media (i.e., the ornamental container industry, landscaping). Previous research supports this in that reduced flurprimidol efficacy in media with pine bark compared with peat based without bark was observed with chrysanthemums (Barrett, 1982).

Flurprimidol leaching from the inert granule, followed by movement through each media, occurred with the initial irrigation event at $4 \mathrm{hr}$ after application (Fig. 1A-E). All treatments exhibited an initial surge on the second irrigation event $(2 \mathrm{~d}$ after application) with a gradual decline over time. The deeper media-sand combination resulted in reduced flurprimidol dissipation constant. Greatest recovery of flurprimidol was $71 \%$ for the sand over the course of the $22 \mathrm{~d}$ of the experiment (Fig. 2A). For hardwood and pine bark plus sand, flurprimidol recoveries were $20.7 \%$ and $14 \%$ at $5 \mathrm{~cm}$ and $25.3 \%$ and $13 \%$ at $10 \mathrm{~cm}$, respectively (Fig. 2B-E).

Studies stopped after 22 irrigation events of sampling when concentrations fell to equal levels for all treatments (Fig. 1). Dissipation of flurprimidol was slow and continuous for the pine and hardwood bark treatments. Although both barks had greater pore space than the sand, this did not result in increased flurprimidol movement. For comparison, pendimethalin moved through pine bark to a depth of 6 to $9 \mathrm{~cm}$ compared with just moving to 0 - to $3-\mathrm{cm}$ depth of a field soil using a crabgrass (Digitaria sanguinalis) bioassay (Simmons and Derr, 2007). Flurprimidol residues from treated grass clippings have caused PGR effects on tomatoes ( $\mathrm{Lyco}$ persicum esculentum) when assayed 14 $\mathrm{d}$ after flurprimidol treatment (Branham and Lickfeldt, 1997). Flurprimidol has water solubility $430 \times$ greater than pendimethalin and is relatively stable as a result of its trifluoromethyl group (Leroux et al., 2008). These variables help to explain why it can be applied to an organic medium such as grass clippings but still has biological activity $14 \mathrm{~d}$ after application.

Flurprimidol recovery from the pine and hardwood barks reached a steady state as a result of its chemical properties. Flurprimidol is a trifluromethyl ether compound that has reduced oxidative metabolism, which reduces dissipation, but also increases its lipophilicity (Leroux et al., 2008). Although pine and hardwood barks are not composted materials, they are plant materials with cellulose and lipid compounds, and flurprimidol has a $\mathrm{K}_{\mathrm{oc}}$ of $185 \mathrm{mg} \cdot \mathrm{L}^{-1}$ (Footprint, 2008). Pine barks have reported effective cation exchange capacities (CEC) ranging from 39 to $52 \mathrm{cmol}^{+} \cdot \mathrm{kg}^{-1}$ (Brown and Pokorny, 1975; Grey et al., 1996; Simmons and Derr, 2007), which can also vary with $\mathrm{pH}$ from 38 to $98 \mathrm{cmol}^{+} \cdot \mathrm{kg}^{-1}$ (Daniels and Wright, 1988). Flurprimidol exhibited a hysteric effect with each subsequent irrigation event for the bark media, indicating adsorption and subsequent release (Fig. 1B-E). This was not observed with the sand (Fig. 1A), which has a low CEC.

Flurprimidol applied as a granular formulation will provide residual activity to plant roots over an extended period of time. However, with high percolation rates for pine bark media (Simmons and Derr, 2007) leading to rapid water loss and low water retention capacity, flurprimidol effectiveness may be lessened if irrigation or rainfall is not applied on a regular basis. Future studies should quantify flurprimidol from media and soil that has been dried for extended periods of time.

\section{Literature Cited}

Anonymous. 1989. Flurprimidol CAS No. 5642591-3 February 22, 1989. US EPA Pesticide Fact Sheet. 4 June 2008. <http://www.fluoridealert. org/pesticides/flurprimidol.epa.facts.1989.htm>.

Barrett, J.E. 1982. Chrysanthemum height control by ancymidol, PP333, and EL-500 dependent on medium composition. HortScience 17:896897.

Bigelow, C.A., B.T. Bunnell, and G.A. Hardebeck. 2007. Monthly flurprimidol applications reduce annual bluegrass populations in a creeping bentgrass fairway. Applied Turfgrass Science. doi: 10.1094/ATS-2007-0508-02-RS

Branham, B.E. and D.W. Lickfeldt. 1997. Effect of pesticide-treated grass clippings used as a mulch on ornamental plants. HortScience 32: 1216-1219.

Brake, J.D., C.R. Boyle, T.N. Chamblee, C.D. Schultz, and E.D. Peebles. 1992. Evaluation of the chemical and physical properties of hardwood bark used as a broiler litter material. Poult. Sci. 71:467-472.

Brown, E.F. and F.A. Pokorny. 1975. Physical and chemical properties of milled pine bark and sand. J. Amer. Doc. Hort. Sci. 100:119-121.

Chand, T. and C.A. Lembi. 1991. Gas chromatography determination of flurprimidol in a submersed aquatic plant (Myriophyllum spicatum), soil, and water. J. Plant Growth Regul. 10:73-78.

Daniels, W.L. and R.W. Wright. 1988. Cation exchange properties of pine bark growing media as influenced by $\mathrm{pH}$, particle size, and cation species. J. Amer. Soc. Hort. Sci. 113: 557-560.

Dermiyati, S.K. and I. Yamamoto. 1997. Relationships between soil properties and sorption behavior of the herbicide halosulfuron-methyl in selected Japanese soils. J. Pestic. Sci. $22: 288-292$
Footprint. 2008. The FOOTPRINT Pesticide Properties DataBase. Database collated by the University of Hertfordshire as part of the EU; funded FOOTPRINT project (FP6-SSP-022704). 9 Sept. 2008. <http://www.eu-footprint.org/ppdb. html>.

Gilliam, C.H.D.C.F. and A. Beasley. 1992. Nontarget herbicide losses from application of granular Ronstar to container nurseries. J. Environ. Hort. 10:175-176.

Grey, T.L., G.R. Wehtje, B.F. Hajek, C.H. Gilliam, G.J. Kever, and P. Pace. 1996. Adsorption, mobility, and filtration of metolachlor in container media. J. Amer. Soc. Hort. Sci. 121:478482

Keel, K.R., C.H. Gilliam, G.R. Wehtje, T.L. Grey, K.J. Keever, and D.J. Eakes. 1998. Herbicide adsorption and release properties of five oxadiazon-coated fertilizers. J. Environ. Hort. 16:230-234.

Krug, B.A., B.E. Whipker, and I. McCall. 2007. Caldium growth with flurprimidol, paclobutrazol, and uniconazole. HortTechnology 17:368370 .

Krug, B.A., B.E. Whipker, I. McCall, and J.M. Dole 2005a. Comparison of flurprimidol to ancymidol, paclobutrazol, and uniconazole for tulip height control. HortTechnology 15:370-373.

Krug, B.A., B.E. Whipker, I. McCall, and J.M. Dole. 2005b. Comparison of flurprimidol to ethephon, paclobutrazol, and uniconazole for hyacinth height control. HortTechnology $15: 872-874$.

Lembi, C.A. and T. Chand. 1992. Response of hydrilla and Eurasian watermilfoil to flurprimidol concentration and exposure times. J. Aquat. Plant Manage. 30:6-9.

Leroux, F., P. Jeschke, and M. Schlosser. 2005. $\propto$-Fluorinated ethers, thioethers, and amines: Anomerically biased species. Chem. Rev. 105: 827-856.

Leroux, F.R., B. Manteau, J.P. Vors, and S Pazenok. 2008. Trifluoromethyl ethers-Synthesis and properties of an unusual substituent. Beilstein J. Org. Chem. doi: 10.3762/bjoc.4.13.

McCullough, P.E., H. Liu, and L.B. McCarty. 2004. Response of 'TifEagle' bermudagrass to seven plant growth regulators. HortScience 39:1759-1762.

Mueller, T.C., D.R. Shaw, and W.W. Witt. 1999 Relative dissipation of acetochlor, alachlor, metolachlor and SAN 582 from three surface soils. Weed Technol. 13:341-346.

Nelson, L.S. 1996. Growth regulation of Eurasian watermilfoil with flurprimidol. J. Plant Growth Regul. 15:33-38.

Nelson, L.S. 1997. Response of hydrilla and American pondweed to flurprimidol. J. Aquat. Plant Mgt. 35:50-54.

Ohmes, G.A., T.C. Mueller, and R.M. Hayes. 2000. Sulfentrazone dissipation in a Tennessee soil. Weed Technol. 14:100-105.

Rademacher, W. 2000. Growth retardants: Effect on gibberellin biosynthesis and other metabolic pathways. Annu. Rev. Plant Physiol. Plant Mol. Biol. 51:501-531.

Simmons, L.D. and J.F. Derr. 2007. Pendimethalin movement through pine bark compared to field soil. Weed Technol. 21:873-876.

Totten, F.W., J.E. Toler, and L.B. McCarty. 2006 'Tifway' bermudagrass growth regulation with the use of trinexapac-ethyl and flurprimidol. Weed Technol. 20:702-705.

Weed Science Society of America. 2007. Herbicide handbook. 9th Ed. WSSA, Champaign, IL. 